A Journal of Agricultural Science Published by the California Agricultural Experiment Station

THE EFFECT OF RIBOFLAVIN AND THE FILTRATE FACTOR ON EGG PRODUCTION AND HATCHABILITY

S. LEPKOVSKY, L. W. TAYLOR, T. H. JUKES, AND H. J. ALMQUIST

\title{
THE VITAMIN-B COMPLEX AS RELATED TO GROWTH AND METABOLISM IN THE PIG
}

E. H. HUGHES 


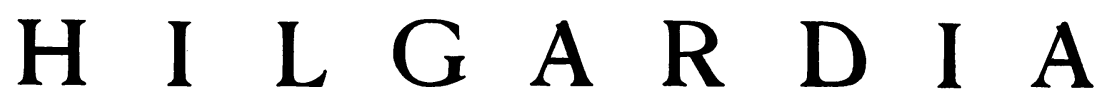

A Journal of Agricultural Science Published by

the California Agricultural Experiment Station

VoL. 11

SEPTEMBER, 1938

No. 10

\section{THE EFFECT OF RIBOFLAVIN AND THE FILTRATE FACTOR ON EGG PRODUCTION AND HATCHABILITY ${ }^{1}$}

S. LEPKOVSKY, ${ }^{2}$ L. W. TAYLOR, ${ }^{8}$ T. H. JUKES, ${ }^{4}$ H. J. ALMQUIST ${ }^{5}$

\section{INTRODUCTION}

Numerous investigations (Bethke and Kennard, 1928; McFarlane, Fulmer, and Jukes, 1930 ; Titus, Byerly, and Ellis, 1933) ${ }^{8}$ have indicated a factor or factors required for hatchability other than the fatsoluble vitamins. The factor or factors seemed associated with some protein concentrates and with such feedstuffs as alfalfa, milk, liver, yeast, and fresh greens. Later work (Halpin, Holmes, and Hart, 1933; Bethke, Record, and Kennard, 1933 ; Heiman, 1935) indicated that vitamin G was the factor responsible. It is now known (Birch, György, and Harris, 1935) that the term "vitamin G" as previously used in the literature covered the complex action of several vitamins. Bethke, Record, and Kennard (1936) have suggested that riboflavin was the active factor responsible for increased hatchability. On the other hand, Smith and Branion (1936) have expressed the opinion that more than one factor in the vitamin-G complex ${ }^{7}$ is involved in hatchability of eggs.

\footnotetext{
${ }^{1}$ Received for publication March 11, 1938.

${ }^{2}$ Associate Professor of Poultry Husbandry and Associate Poultry Husbandman in the Experiment Station.

${ }^{3}$ Associate Professor of Poultry Husbandry and Associate Poultry Husbandman in the Experiment Station.

- Instructor in Poultry Husbandry and Junior Poultry Husbandman in the Experiment Station.

${ }^{5}$ Assistant Professor of Poultry Husbandry and Assistant Poultry Husbandman in the Experiment Station.

"See "Literature Cited" at the end of this paper for complete data on citations, which are referred to in the text by author and date of publication.

${ }^{7}$ The vitamin-G complex as used here refers to the combination of the filtrate factor and riboflavin. Riboflavin was formerly known as "lactoflavin" or "vitamin $\mathrm{B}_{2}$ " (Euler, et al., 1935) ; Kuhn, György, and Wagner-Jauregg, 1933) or as "vitamin G" (Sherman and Smith, 1931). The filtrate factor is identical with the "vitamin $\mathbf{B}_{2}$ " of Elvehjem and Koehn (1935) and the "chick antipellagric factor" of Ringrose, Norris, and Heuser (1931).
} 
Two members of the vitamin-G complex have been shown to be necessary for the chick: riboflavin and the filtrate factor (Lepkovsky and Jukes, 1935). Both of these were studied in the present investigation. Riboflavin concentrates and crystalline riboflavin were used, but the filtrate factor was not available in crystalline form. Concentrates of the latter were used which were freed as far as possible from all the known vitamins for which tests are available. The investigations were continued over a period of two years, 1935-36 and 1936-37.

\section{EXPERIMENTAL PROCEDURE}

Selection of Stock.-Single-Comb White Leghorn hens which had completed their first year of production were segregated into lots with an equal number of birds per pen. The previous production records of the birds were known, and they were distributed into pens as evenly as possible with respect to an estimated potential egg-producing ability. Total past egg production, the persistency of production, and the physical condition of the bird were considered as indicative of future egg-production ability.

Between the time the pens were set up in 1935 and the beginning of the experimental feeding, a varying amount of mortality disturbed the equality of numbers of birds between the pens. The actual number of birds per pen at the beginning varied from 24 to 27 . In the year 1936-37, each pen contained 24 yearling hens at the time the experimental feeding began.

Rations and Supplements.-In the 1935-36 experiments, all 8 pens were placed on the unsupplemented rations from November 9 to December 8, 1935. From December 9, 1935, through May 31, 1936, the supplements were added to the rations. In this year two pens of birds were changed to different supplements during the month of June.

In 1936-37, no period of preliminary depletion was attempted, and the birds were changed from the standard laying mash used at this station to the variously supplemented rations on December 1 and were so fed through May 31.

The composition of the three rations used is given in table 1 . Ration 2 was chosen as a typical practical diet supposedly complete in all nutritional essentials. Ration 1 represented a similar ration from which the usual practical vitamin-G sources had been omitted. Ration 3 was formulated in an attempt to supply a simplified diet which would be more deficient in riboflavin and the filtrate factor.

The barley, wheat, wheat bran, corn, sardine meal (dehydrated with superheated steam), casein, skim milk, sardine oil, bone meal, oystershell, 
polished rice, and soybean oil used in these rations were products of commerce. The extracted sardine meal was a special product extracted with a hydrocarbon solvent. The special salt was sodium chloride plus 0.010 per cent iron as ferrous sulfate and 0.001 per cent copper as copper sulfate. These rations were supplemented as detailed in table 2.

Preparation of Supplements.-The 1935-36 riboflavin fuller's-earth adsorbate was prepared by shaking whey with fuller's earth. It was

TABLE 1

Composimion of Rations UsEd IN HatchabiLIty EXPERIMENTS, 1935-36 AND 1936-37

(In parts by weight)

\begin{tabular}{|c|c|c|c|}
\hline Component & Ration 1 & Ration 2 & Ration 3 \\
\hline 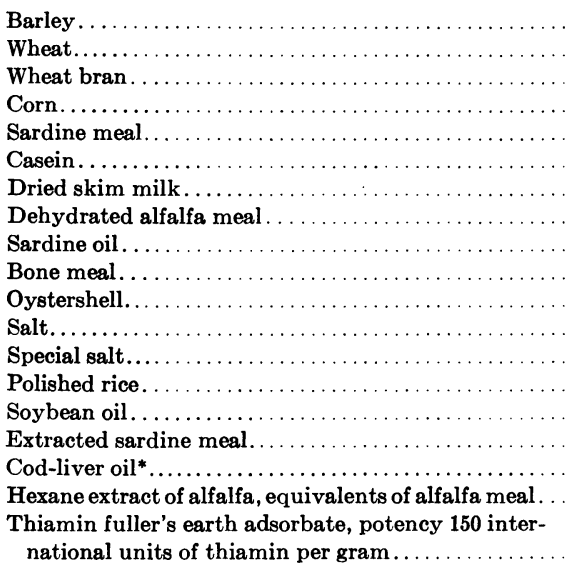 & $\begin{array}{r}40.0 \\
26.0 \\
5.0 \\
20.0 \\
6.0 \\
1.0 \\
\ldots \\
\cdots \\
\ldots \\
1.0 \\
0.5 \\
0.5 \\
\ldots \\
\cdots \\
\ldots \\
\ldots . \\
0.5 \\
5.0 \\
\ldots\end{array}$ & $\begin{array}{c}40.0 \\
20.0 \\
5.0 \\
20.0 \\
6.0 \\
\ldots . \\
2.5 \\
4.0 \\
\mathbf{0 . 2 5} \\
\mathbf{1 . 0} \\
\mathbf{0 . 7 5} \\
\mathbf{0 . 5} \\
\ldots . \\
\ldots \\
\ldots . \\
\ldots \\
\ldots \\
\ldots \\
\ldots \\
\ldots\end{array}$ & $\begin{array}{r}\ldots \\
\ldots \\
\ldots \\
\ldots \\
\ldots \\
\ldots \\
\ldots \\
\ldots \\
\ldots \ldots \\
\ldots . \\
0.5 \\
0.5 \\
\ldots . \\
0.5 \\
80.0 \\
3.5 \\
15.0 \\
0.5 \\
5.0 \\
\\
1.0\end{array}$ \\
\hline
\end{tabular}

* The cod-liver oil contained 2,000 international units of vitamin A and 350 U.S.P. units of vitamin D per gram.

found by assay to contain about 50-60 units of riboflavin per gram. Three riboflavin concentrates, varying in potency from 10,000 to 50,000 units per gram, were fed successively during the course of the experiment.

The thiamin fuller's-earth adsorbate was prepared by treating an extract of rice bran with fuller's earth. It was found by assay to contain about 150 international units of thiamin per gram.

The crude filtrate factor was prepared by concentrating rice-bran extract to a heavy syrup, after most of the thiamin and riboflavin had been removed with fuller's earth. The refined filtrate factor was prepared by treating the crude filtrate-factor preparation with methanol to a concentration of about 80 per cent, rejecting the precipitate, and concen- 
trating the filtrate to a thick syrup. These extracts, used in 1935-36, contained the filtrate factor and factor 1 (Lepkovsky, Jukes, and Krause, 1936).

In 1936-37, the filtrate factor was prepared from the wash liquor remaining after the removal of lactose from whey. This liquor was ex-

TABLE 2

SUPPlements Used With Basal Rations, 1935-36 AND 1936-37

\begin{tabular}{|c|c|c|}
\hline Pen No. & Supplement & $\begin{array}{c}\text { Amount per lb. } \\
\text { of feed }\end{array}$ \\
\hline \multicolumn{3}{|c|}{ Ration 2, 1935-36 } \\
\hline $\begin{array}{l}\text { Pen } 13 \\
\text { Pen } 14 \\
\text { Pen } 15\end{array}$ & 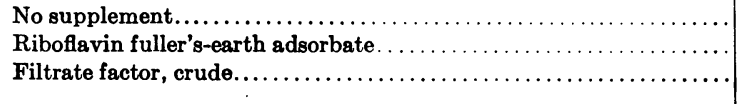 & $\begin{array}{r}250 \text { units } \\
80 \text { units }\end{array}$ \\
\hline \multicolumn{3}{|c|}{ Ration 1, 1935-36 } \\
\hline $\begin{array}{l}\text { Pen 16 } \\
\text { Pen } 17 \\
\text { Pen } 18 \\
\text { Pen } 19 \\
\text { Pen } 20\end{array}$ & 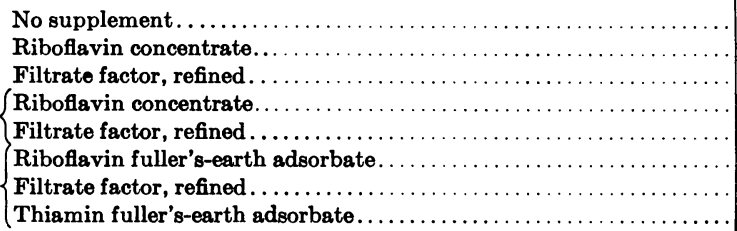 & $\begin{array}{l}500 \text { units } \\
200 \text { units } \\
500 \text { units } \\
200 \text { units } \\
500 \text { units } \\
200 \text { units } \\
300 \text { units }\end{array}$ \\
\hline
\end{tabular}

Ration 3, 1936-37

\begin{tabular}{|c|c|c|}
\hline $\begin{array}{ll}\text { Pen } & 5 \\
\text { Pen } & 6 \\
\text { Pen } 7 \\
\text { Pen } 8\end{array}$ & 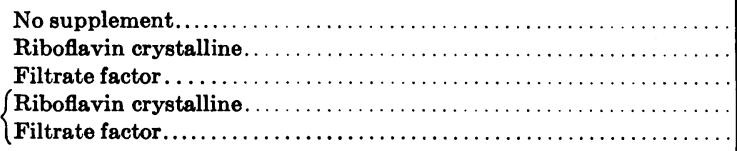 & $\begin{array}{l}2.5 \text { milligrams } \\
200 \text { units } \\
2.5 \text { milligrams } \\
200 \text { units }\end{array}$ \\
\hline \multicolumn{3}{|c|}{ Ration 1, 1936-37 } \\
\hline $\begin{array}{l}\text { Pen 9 } \\
\text { Pen } 10 \\
\text { Pen } 11 \\
\text { Pen } 12\end{array}$ & 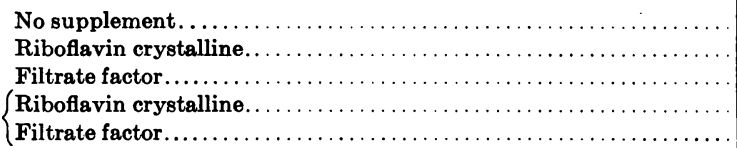 & $\begin{array}{l}\ldots \ldots \ldots \\
2.5 \text { milligrams } \\
200 \text { units } \\
2.5 \text { milligrams } \\
200 \text { units }\end{array}$ \\
\hline
\end{tabular}

tracted with acetone or mixtures of acetone and ethyl or methyl alcohol. Suitable concentrates assaying about 40 units (Jukes, 1937b) per gram were used. When the potency was lower, the concentrate was increased so that as nearly as possible the same amount of vitamin (filtrate factor) was fed throughout the investigation. The concentrate was exhaustively treated with fuller's earth to remove riboflavin and factor 1 (Lepkovsky, 
Jukes, and Krause, 1936). Analytically, as far as available methods for detection of vitamins permitted, the concentrate proved to carry only one of the known vitamins - the filtrate factor.

Biological Methods.-The methods of Lepkovsky and Jukes (1935) and Jukes (1937b) were used to assay concentrates for their filtratefactor values. The unit is defined (Jukes, 1937b) as "one-tenth of the amount which will just provide for maximal growth when fed daily to a chick 3 weeks old in conjunction with the heated diet under the conditions described."

For the evaluation of riboflavin, rats were used as experimental animals. The following basal diet was used : casein, 24 parts; hydrogenated cottonseed oil (Crisco), 10; sucrose, 57 ; salts (McCollum and Simmonds, 1918), 4; and cod-liver oil, 2. The casein was washed with acidulated water (0.1 per cent acetic acid), dissolved in dilute sodium hydroxide, and reprecipitated with either acetic or sulfuric acid. The precipitated casein was again washed several times with water, partially dehydrated with alcohol and acetone, and dried in an oven at about $60-80^{\circ} \mathrm{C}$. Care was taken to supply adequate thiamin and factors 1 and 2 (Lepkovsky, Jukes, and Krause, 1936), in order to leave riboflavin as the only known limiting factor. Thiamin was supplied as a $\mathrm{Ba}(\mathrm{OH})_{2}$ eluate from a fuller's-earth adsorbate prepared from rice bran. Such concentrates, administered daily in amounts furnishing about 10 international units of thiamin, supplied practically no riboflavin. Factor 1 and factor 2 concentrates were prepared as described by Lepkovsky, Jukes, and Krause (1936). All vitamin concentrates fed were first assayed and the amounts given so adjusted as to insure approximate vitamin intake corresponding to levels called for by the investigation.

The basal diet was fed during a depletion period of 10 to 12 days, after which vitamin supplements other than riboflavin were fed. When rats no longer gained weight, the riboflavin was given.

Five micrograms of the erystalline riboflavin used in these investigations produced a gain of more than 3 grams weekly; 3 grams is the unit gain suggested by Bourquin and Sherman (1931). This is in close agreement with results obtained by other investigators with crystalline riboflavin (Kuhn, Rudy, and Wagner-Jauregg, 1933; Bender and Supplee, 1937). It is, therefore, possible to assume that our preparation of crystalline riboflavin contained little or no impurity.

Care of Birds.-All birds were housed in pens of the same size and construction and were given access to completely wire-enclosed concrete yards. Complete trapnest records were kept, and the eggs produced were so marked that the hatchability record of each hen was obtained. 
During periods of production of fertile eggs, male birds were rotated through the series of pens, the changes being made daily. At other times the male birds were removed.

Feed was mixed in 100-pound batches for each pen; each batch was usually sufficient for 3 to 6 weeks of feeding. Oystershell, limestone, and granite grit were available in hoppers at all times.

Eggs were saved for hatching in 10-consecutive-day periods and were then incubated under normal conditions. Immediately after certain of these periods, eggs were saved for later feeding experiments and were kept in cold storage $\left(0^{\circ} \mathrm{C}\right)$ until used.

\section{DISCUSSION OF RESULTS ON EGG PRODUCTION}

In the 1935-36 series (table 3, first two sections), little difference in egg production occurred during December between the various pens. During January, marked differences appeared, increased egg production apparently resulting from the addition of riboflavin to both rations 1 and 2 . Differences were less marked during the remaining months of the experiment, which represent the normal season of heavy egg production. However, the highest egg yields came from hens receiving rations to which riboflavin supplements were added. The total number of eggs laid during the whole experiment was definitely greater in the pens receiving added riboflavin supplements.

Egg production on ration 2 during January was apparently stimulated by addition of riboflavin, in spite of the fact that the diet contained 4.0 per cent of alfalfa meal and 2.5 per cent of dried skim milk as natural sources of riboflavin. Addition of riboflavin either to ration 1 or to ration 2 seemed to stimulate egg production to a greater extent during the winter months than when egg production is normally high.

Pen 20, receiving thiamin in addition to riboflavin and filtrate factor, had the highest egg production, but the difference between this and the production of pen 17 , receiving riboflavin, is of doubtful significance. Addition of the filtrate factor had no effect in any instance.

In 1936-37, repetition of riboflavin and filtrate-factor supplementation of ration 1 (table 3 ) gave results closely similar to those obtained in 1935-36.

Ration 3 was used in an effort to secure a ration lower in riboflavin and the filtrate factor than ration 1 . It was hoped that by this means a point might be reached at which the filtrate-factor content would be a limiting influence in hatchability. A similar ration supplemented with brewers' yeast (Almquist and Stokstad, 1935) had been repeatedly found to produce excellent growth in chicks. In the present investigation, the brewers' 
TABLE 3

Egg Production and Mortality

\begin{tabular}{|c|c|c|c|c|c|c|c|c|c|}
\hline \multirow[b]{2}{*}{ Supplement } & \multicolumn{8}{|c|}{ Average egg production* } & \multirow{2}{*}{$\begin{array}{c}\text { Per } \\
\text { cent } \\
\text { mor- } \\
\text { tality } \\
\text { Dec.- } \\
\text { May }\end{array}$} \\
\hline & $\begin{array}{c}\text { Before } \\
\text { Dec. } \dagger \\
.\end{array}$ & Dec. & Jan. & Feb. & Mar. & April & May & $\begin{array}{l}\text { Total, } \\
\text { Dec.- } \\
\text { May }\end{array}$ & \\
\hline \multicolumn{10}{|c|}{ Ration 2, 1935-36 } \\
\hline Pen 13, no supplement. . & 230.3 & 5.1 & 6.8 & 13.7 & 18.2 & 18.6 & 15.6 & 78.0 & 20.8 \\
\hline Pen 14, riboflavin........ & 226.0 & 3.4 & 10.3 & 14.5 & 18.3 & 20.1 & 18.0 & 84.6 & 14.8 \\
\hline Pen 15, filtrate factor. & 224.2 & 2.3 & 6.9 & 14.3 & 17.3 & 16.3 & 15.4 & 72.5 & 23.1 \\
\hline
\end{tabular}

Ration 1, 1935-36

\begin{tabular}{c|r|r|r|r|r|r|r|r|c}
\hline Pen 16, no supplement... & 224.9 & 3.8 & 3.3 & 8.6 & 15.0 & 16.9 & 17.1 & 64.7 & 12.0 \\
Pen 17, riboflavin....... & 229.4 & 4.4 & 11.0 & 15.0 & 19.1 & 17.8 & 18.4 & 85.7 & 14.8 \\
Pen 18, filtrate factor.... & 224.0 & 2.8 & 5.7 & 10.0 & 14.8 & 15.0 & 17.0 & 65.3 & 34.6 \\
Pen 19, riboflavin + fil- & & & & & & & & & \\
trate factor........... & 227.5 & 2.3 & 10.5 & 13.9 & 16.5 & 17.7 & 17.9 & 78.8 & 29.6 \\
Pen 20, riboflavin + fil- & & & & & & & & & \\
trate factor + thiamin.. & 220.3 & 3.4 & 11.5 & 15.5 & 17.7 & 21.2 & 22.1 & 91.4 & 22.2 \\
\hline
\end{tabular}

Ration 1, 1936-37

\begin{tabular}{|c|c|c|c|c|c|c|c|c|c|}
\hline Pen 9, no supplement. ... & 246.0 & 2.6 & 4.3 & 9.7 & 16.3 & 16.9 & 16.7 & 66.5 & 8.3 \\
\hline Pen 10 , riboflavin ........ & 246.3 & 3.4 & 9.3 & 15.1 & 20.2 & 20.0 & 18.4 & 86.4 & 12.5 \\
\hline Pen 11, filtrate factor.... & 249.5 & 3.2 & 4.4 & 8.5 & 15.4 & 18.7 & 17.7 & 67.9 & 12.5 \\
\hline $\begin{array}{l}\text { Pen } 12 \text {, riboflavin }+ \text { fil- } \\
\text { trate factor........... }\end{array}$ & 248.5 & 7.0 & 12.3 & 12.7 & 19.9 & 18.8 & 17.7 & 88.4 & 12.5 \\
\hline \multicolumn{10}{|c|}{ Ration 3, 1936-37 } \\
\hline Pen 5, no supplement. . & 251.0 & 1.9 & 0.3 & 1.9 & 9.8 & 14.2 & 13.6 & 41.7 & 37.5 \\
\hline Pen 6 , riboflavin....... & 250.3 & 3.0 & 3.7 & 6.8 & 7.3 & 6.1 & 4.5 & 31.4 & 58.3 \\
\hline \multirow{2}{*}{$\begin{array}{l}\text { Pen } 7 \text {, filtrate factor..... } \\
\text { Pen } 8 \text {, riboflavin }+ \text { fil- } \\
\quad \text { trate factor............. }\end{array}$} & 255.1 & 2.7 & 0.2 & 1.3 & 9.3 & 13.7 & 11.6 & 38.8 & 29.2 \\
\hline & 250.4 & 4.8 & 9.1 & 9.6 & 10.6 & 11.0 & 10.1 & 55.2 & 45.8 \\
\hline
\end{tabular}

* The egg-production data represent an approximation of a hen-month basis of calculation. Dead birds or birds removed for pathological reasons are credited as in the pen to the end of the nearest halfmonth period from the date of removal.

t Pre-experimental period.

yeast was replaced with thiamin, in order to keep the basal ration low in riboflavin and the filtrate factor. Ration 3 was then supplemented with each and with both of these factors.

The results are given in table 3 . While riboflavin increased egg production in the winter months on both rations, it actually caused a poorer production in ration 3 during April and May. With ration 1, no such result was obtained.

The whites of the eggs from pens 10 and 12 (ration 1, riboflavin-sup- 
plemented) had a pronounced yellow-green tinge in contrast to the almost colorless appearance of the whites of eggs from pens 9 and 11 (no riboflavin supplement). This difference is illustrated in figure 1 .

Statistical Significance of Results.-The variance of monthly average egg production between the two years of experimentation on ration 1 and between rations 1 and 3 for the year 1936-37 was calculated (table 4). From the analysis of results on ration 1 , it is possible to state that no

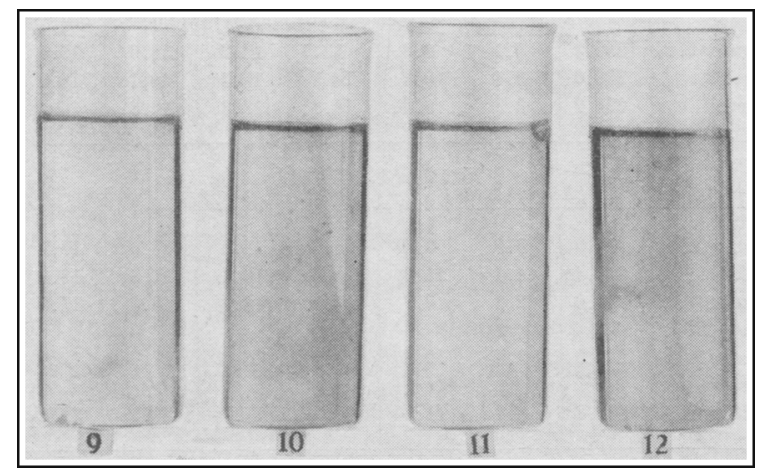

Fig. 1.-Color of egg white as influenced by feeding riboflavin to hens. The darker shade of whites from eggs from pens 10 and 12 is produced by a greenish-yellow pigment.

significant effect on egg production can be attributed to the filtrate factor or to any interaction of the filtrate factor with other variables. Further, the difference between the results obtained in 1935-36 and in 1936-37 on ration 1 is of questionable significance. The seasonal effect measured by monthly production is, of course, highly significant since the birds used were hens recovering from a molt. The effect of riboflavin on egg production is of unquestionable significance, and the evidence for a differential interaction between riboflavin and month of production also is highly significant. From these results, it is clear that riboflavin greatly improved egg production on this basal ration and that the effect was more pronounced during the winter months.

Comparison of variance of egg production of the pens on rations 1 and 3 during the year 1936-37 shows a very high significance for the difference in results obtained between the two rations. Again the effect of riboflavin and the interaction between riboflavin and months of production prove to be highly significant. The difference between the effect of addition of riboflavin to ration 1 and to ration 3 is likewise highly significant. For the effect of the filtrate factor, the data indicate questionable significance. The difference in response of birds on the two rations 


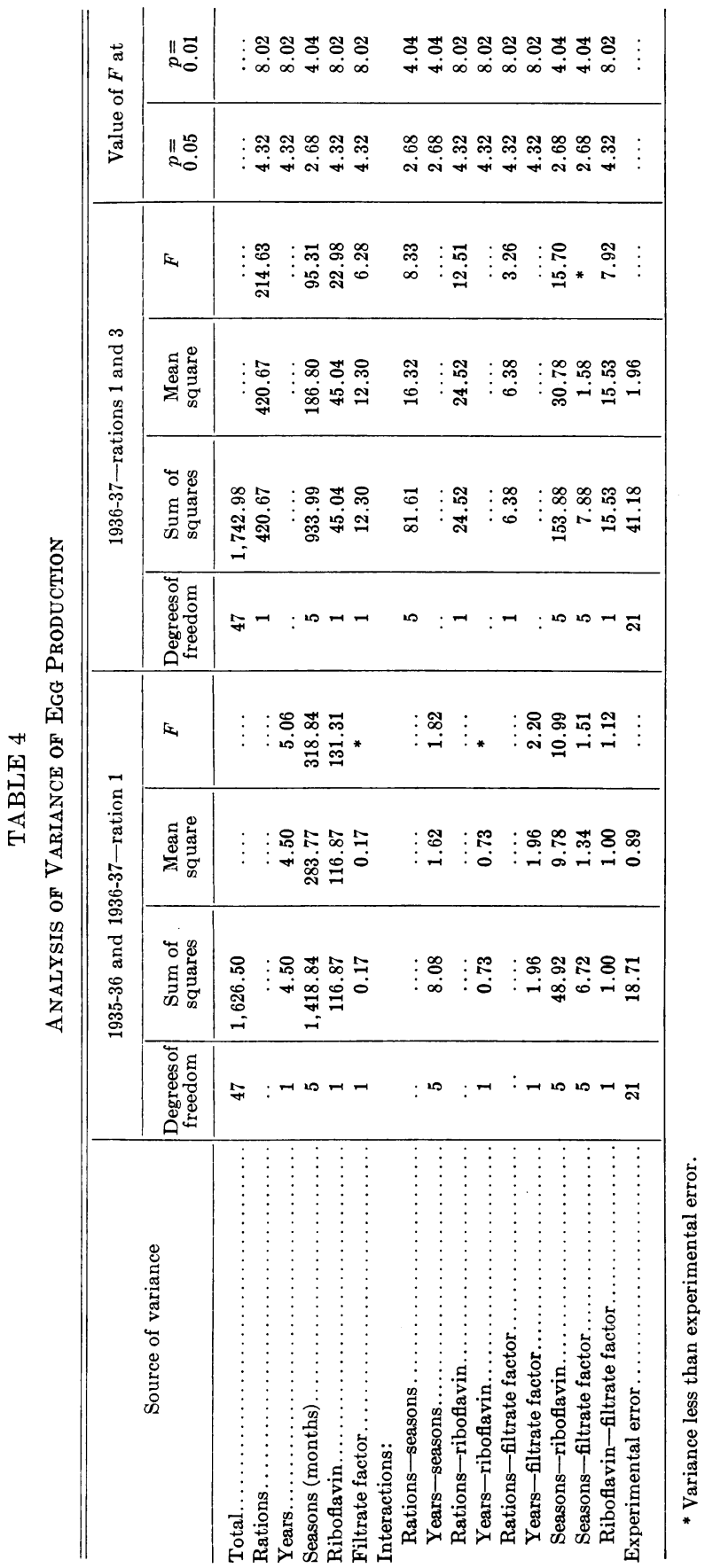


according to season, as indicated by interaction between the rations and months of production, is highly significant.

The above results provide strong evidence that the riboflavin level of the diet is an important factor controlling the egg production of hens in the winter months following the first adult molt. The addition of riboflavin stimulated hens to a better winter production similar to that induced by artificial lighting. This is not in agreement with results obtained by Heiman (1935) and Davis, Norris, and Heuser (1938 $a$ and $b$ ), who found no relation between vitamin-G level and egg production.

\section{ADULT MORTALITY}

The per-cent mortality of hens during the experiments is given in table 3 , last column. While the amount of loss varied between pens and between years, no definite trends are noticeable except with respect to ration 3 , which produced a relatively high mortality. Analysis of mortality, pre-

TABLE 5

Analysis of Mortality Data

\begin{tabular}{|c|c|c|}
\hline Rations or supplements compared & $x^{2}$ & $\begin{array}{l}P \text { lies within } \\
\text { limits }\end{array}$ \\
\hline Ration 1 vs. ration $3(1936-37) \ldots \ldots \ldots$ & 22.4547 & $<0.01$ \\
\hline Ration 1, 1935-36, vs. ration $1,1936-37 \ldots \ldots \ldots \ldots \ldots$ & 4.5311 & $0.05-0.02$ \\
\hline Riboflavin vs. no riboflavin (both years combined)........ & 0.0079 & $.95-.90$ \\
\hline Filtrate factor vs. no filtrate factor (both years combined)........ & 0.0029 & $.95-.98$ \\
\hline Riboflavin vs. riboflavin + filtrate factor (both years combined).... & 1.0794 & $.30-.20$ \\
\hline Filtrate factor vs. riboflavin + filtrate factor (both years combined) & 0.0849 & $.80-.70$ \\
\hline Riboflavin vs. no riboflavin $(\mathbf{1 9 3 5 - 3 6 )} \ldots \ldots \ldots \ldots \ldots \ldots \ldots \ldots \ldots$ & 0.0269 & $.90-.80$ \\
\hline Filtrate factor vs. no filtrate factor $(1936-37) \ldots \ldots \ldots \ldots \ldots \ldots \ldots$ & 5.0621 & $0.05-0.02$ \\
\hline
\end{tabular}

sented in table 5 , shows that ration 3 was significantly different from ration 1 in this respect, whereas all other differences in mortality obtained were not significant or were questionably so.

With the exception of pen 8 , all groups of surviving hens on ration 3 were in poorer physical condition at the conclusion of the experiment than similar lots of birds on ration 1 . The following data represent the average body weight on May 31, 1937, for the various pens :

\begin{tabular}{|c|c|c|c|}
\hline Ration 3 & $\begin{array}{c}\text { Average weight, } \\
\text { in grams }\end{array}$ & Ration 1 & $\begin{array}{c}\text { Average weight, } \\
\text { in grams }\end{array}$ \\
\hline Pen 5 & $\ldots 1,547$ & Pen 9.. & $\ldots 1,661$ \\
\hline Pen 6 . & $\ldots 1,565$ & Pen 10. & $\ldots 1,748$ \\
\hline Pen 7. & $\ldots 1,489$ & Pen 11. & . . 1,698 \\
\hline Pen 8. & $\ldots 1,666$ & Pen 12 . & $\ldots 1,730$ \\
\hline
\end{tabular}




\section{FURTHER EVIDENCE ON THE NATURE OF DEFICIENCIES IN RATION 3}

In order to obtain additional information on ration 3 , with and without its various supplements, week-old cockerels were put on a heated dietJukes's (1937b) diet $80 \mathrm{G}$-for a depletion period of one week. They were then fed ration 3 with and without vitamin supplements for 10 days. Ration 3 was supplemented with 5.0 per cent heated casein to equalize its protein value with that of the heated diet. A negative control group was continued on diet $80 \mathrm{G}$ and a positive control group was fed diet $80 \mathrm{G}$ plus 6 per cent liver filtrate. The results obtained follow :

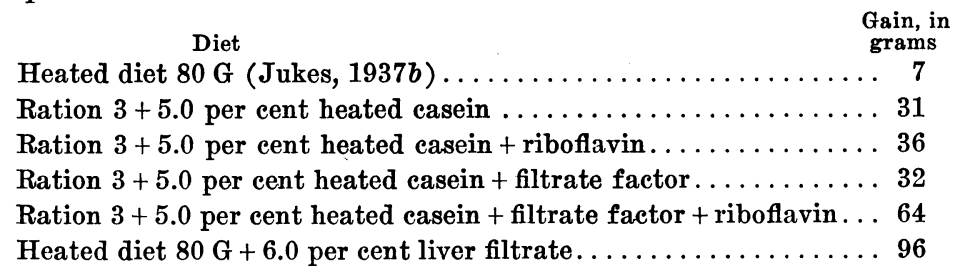

Growth results from this limited experiment indicated that ration 3 was low in both the filtrate factor and riboflavin, as well as in some additional factor supplied by the diet fed to the positive control group. The results are in harmony with those on egg production and mortality presented above in indicating that ration 3 was deficient in a factor other than riboflavin and the filtrate factor. The egg-production records showed increased production with riboflavin at first, but later the riboflavin appeared actually to be detrimental, which suggests the progressive exhaustion of a vital factor. Even when both riboflavin and the filtrate factor were supplied, the production fell short of that obtained on ration 1 without supplements. Also, during the seasonal months of usual heavy lay, the egg production was comparatively poor. It is not definitely known whether the improvement in production of pen 8 (ration 3 plus riboflavin and the filtrate factor) over that of pen 6 (ration 3 plus riboflavin) was due to the effect of the filtrate factor or to the presence of a small amount of an unknown factor in the concentrate fed as a source of filtrate factor.

\section{HATCHABILITY}

The results obtained from hatching the eggs laid during 10-day periods for each month from January through May in 1936 and 1937 are recorded in table 6 .

Addition of the filtrate factor seemed to have no effect on the hatchability of eggs laid by hens receiving rations 1 and 2 . This is particularly 


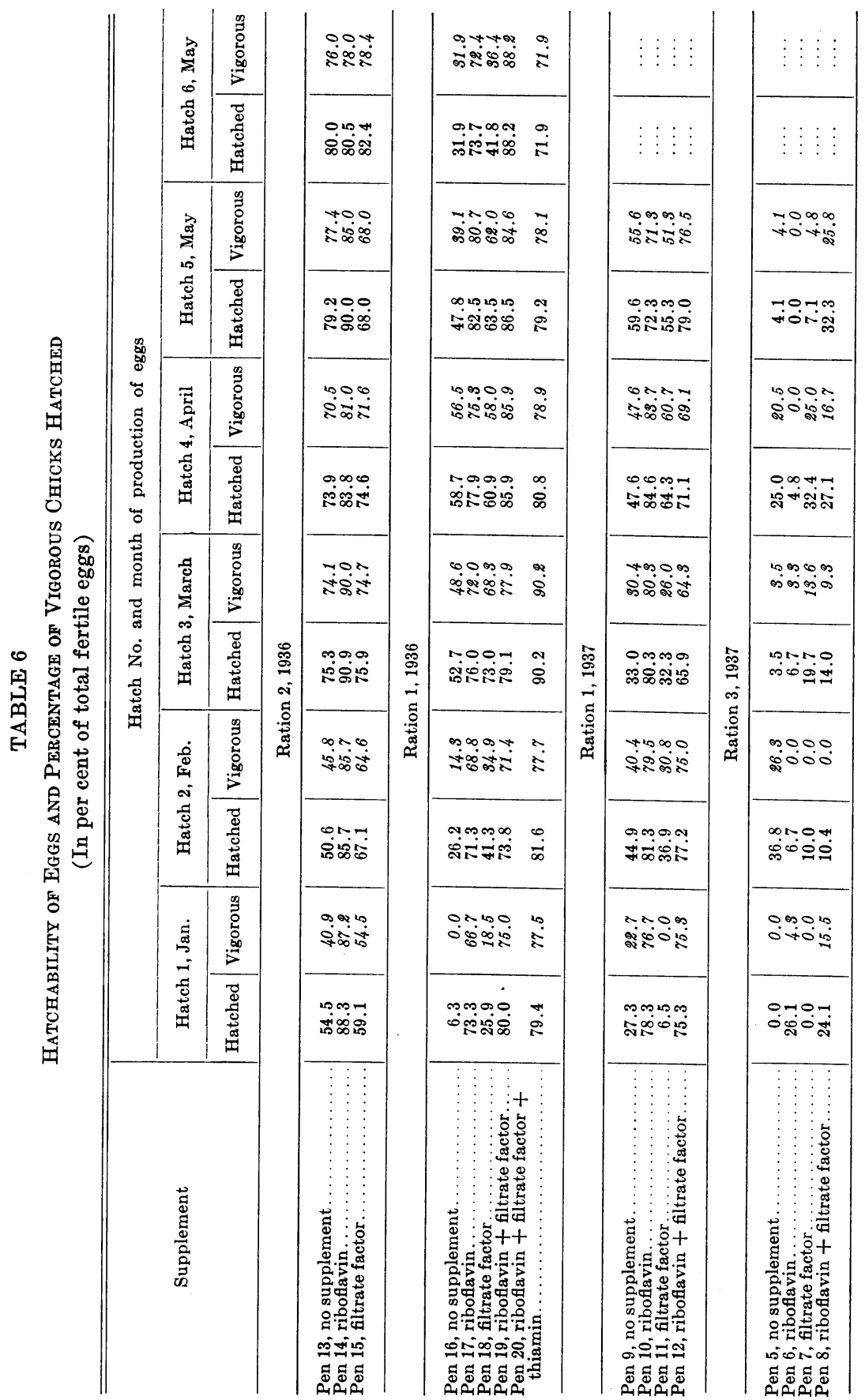


evident from ration 1 in 1937, when the filtrate-factor concentrate was prepared from whey and was carefully freed from riboflavin (table 6, pen 11). In 1936, however, the hatchability of the eggs from pen 18 fed ration 1 +filtrate factor was uniformly better than the hatchability of eggs from pen 16 fed ration 1 unsupplemented. On ration 2, eggs from pen 15 receiving filtrate factor hatched but slightly better than those from pen 13 receiving no supplement. Possibly the 1936 results were produced either by a small amount of riboflavin remaining in the rice-bran filtrate-factor preparation, or by some other factor in this preparation.

The addition of riboflavin to ration 1 produced a striking increase in hatchability (table 6, pens 17 and 10), even in 1937, when only $2.5 \mathrm{mg}$ of riboflavin were added per pound of feed. There seemed to be no additive effect from a combination of riboflavin and filtrate factor. Evidently rations 1 and 2 supplied enough filtrate factor for good hatchability. The addition of a thiamin supplement to supplements of riboflavin and filtrate factor (table 6, pen 20 ) had no noticeable effect upon hatchability.

Ration 2, containing 4 per cent of alfalfa meal and 2.5 per cent of dried skim milk, did not supply sufficient riboflavin for uniformly high hatchability, since addition of this vitamin (table 6, pen 14) produced a marked increase in hatchability, especially during the winter months of January and February. This finding indicates that many rations which have been considered to be sufficiently supplied with riboflavin may not contain enough for maximum hatchability at all seasons.

An attempt was made to improve the hatchability of eggs laid by hens on ration 1 without riboflavin (pens 16 and 18) by adding a riboflavin concentrate after the experimental period was over. Beginning on June 1, 800 milligrams of a concentrate supplying 50,000 units of riboflavin per gram was added to the 100 pounds of ration, or 400 units per pound. Eggs were collected for 20 days, beginning June 7, and two hatches were made. The results follow :

$\begin{array}{ccc} & \text { Per Cent of Vigorous Chicks Hatched } \\ \text { Pen } & \text { May, 1936, } & \text { June, 1936, } \\ \text { No. } & \text { before supplementation } & \text { after supplementation } \\ 16 & 31.9 & 71.0 \\ 18 & 36.4 & 82.9\end{array}$

The effect of the riboflavin on hatchability was prompt and striking: riboflavin seemed to be transferred to the egg almost immediately, a greatly improved hatchability of eggs being effected within 7 days.

The hatchability of the eggs produced by hens on ration 3 was uniformly poor. A deficiency of an unknown factor or factors is probably 
indicated, and the possibility of this deficiency is further supported by the low egg production on the same ration (table 3). Riboflavin seemed to increase hatchability somewhat at first (hatch 1, table 6), but later actually depressed it below the hatchability obtained on the basal diet, especially in hatches 2 and 4 . In hatch 5 , the best results were obtained

TABLE 7

Relation of Types of Embryonic Mor'tality to Riboflavin Supplementation in Breeding Hen Diets

(In per cent of total fertile eggs)

\begin{tabular}{|c|c|c|c|c|c|c|}
\hline \multirow{2}{*}{$\begin{array}{l}\text { Ration and supplement } \\
\text { fed to hens }\end{array}$} & \multirow{2}{*}{ Edema } & \multirow{2}{*}{$\begin{array}{l}\text { Clubbed } \\
\text { down }\end{array}$} & \multicolumn{2}{|c|}{ Wolffian bodies } & \multirow{2}{*}{$\begin{array}{l}\text { Dwarf } \\
\text { type }\end{array}$} & \multirow{2}{*}{ Anemia } \\
\hline & & & Caseous & Swollen* & & \\
\hline \multicolumn{7}{|l|}{ Ration 2, 1935-36 } \\
\hline Without riboflavin. & 3.56 & 3.88 & 0.91 & $\ldots$ & 0.53 & 1.83 \\
\hline With riboflavin........ & 0.00 & 0.00 & 0.00 & - & 0.00 & 1.27 \\
\hline \multicolumn{7}{|l|}{ Ration 1, 1935-36 } \\
\hline Without riboflavin. & 8.10 & 6.65 & 2.51 & - & 1.14 & 6.06 \\
\hline With riboflavin...... & 0.20 & 0.00 & 0.07 & $\ldots$ & 0.07 & 1.45 \\
\hline \multicolumn{7}{|l|}{ Ration 1, 1936-37 } \\
\hline Without riboflavin...... & 13.68 & 13.08 & 4.65 & 0.51 & 2.78 & 4.85 \\
\hline With riboflavin...... & 0.69 & 0.11 & 0.00 & 0.00 & 0.00 & 0.87 \\
\hline \multicolumn{7}{|l|}{ Ration 3, 1936-37 } \\
\hline Without riboflavin...... & 15.55 & 12.57 & 3.67 & 3.18 & 2.65 & 4.53 \\
\hline With riboflavin.......... & 2.94 & 5.09 & 0.20 & 1.58 & 1.57 & 7.28 \\
\hline
\end{tabular}

* Recorded only in 1937.

when ration 3 was supplemented with both filtrate factor and riboflavin. The presence of riboflavin in the eggs from hens fed riboflavin-supplemented rations in pens 6 and 8 was indicated by the greenish-yellow color of the albumen.

\section{CHARACTER OF EMBRYONIC MORTALITY}

All eggs candled out from the experimental hatches were broken and examined for fertility as indicated by the presence of embryonic remains. All unhatched eggs were also examined, and some thirty-five types of embryonic defects were recorded. Of the various types of embryonic mortality, only those presented in table 7 had any association with the vitamin supplements used. In no instance was there a consistent and significant difference with respect to types of mortality produced in the presence of the filtrate-factor supplement.

Riboflavin was evidently successful in eliminating or materially reducing the incidence of edema, degeneration of the Wolffian bodies, defective down, and dwarf-type embryos. 
An edema was commonly found in embryos dying between 9- and 14day stages of embryonic development (fig. 2). Occasionally, but not usually, an edema was found in more advanced stages. The type of edematous condition found here seems comparable to that produced by Smith and Branion (1936) with rations deficient in riboflavin. It does not

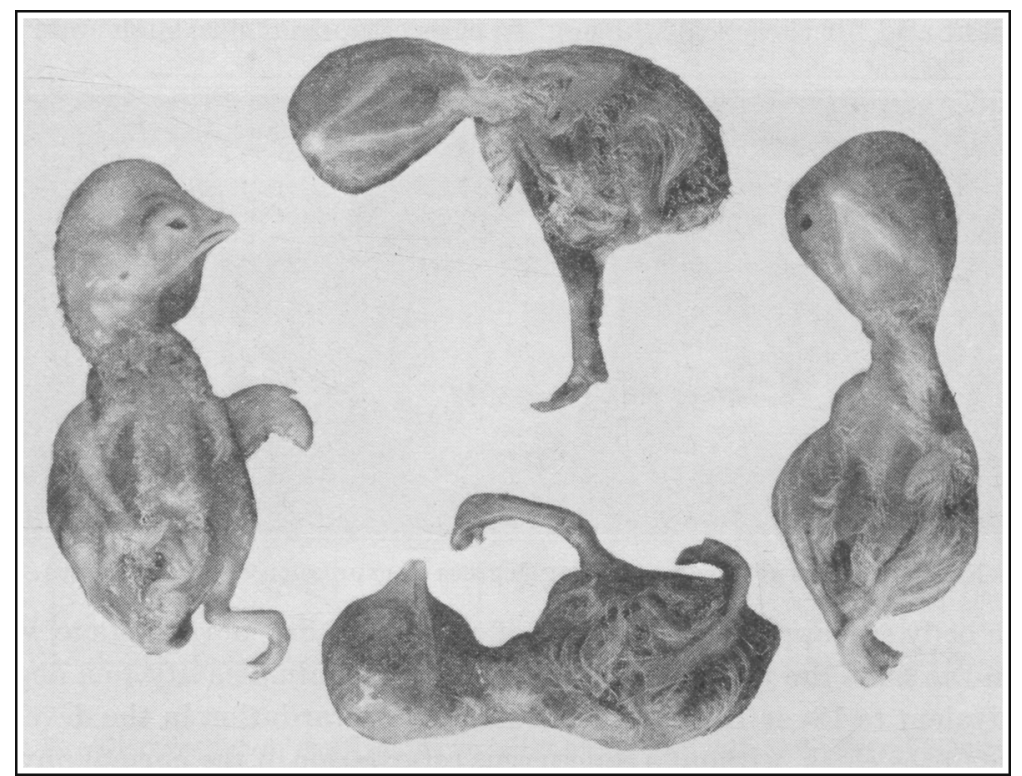

Fig. 2.-Edematous embryos of 13- to 15-day incubation stages. The embryo on the left also exhibits clubbed down and that on right chondrodystrophy.

resemble the characteristic edemata produced by manganese deficiency (Lyons and Insko, 1937) or by selenium poisoning (Poley, Moxon, and Franke, 1937).

Degeneration of the embryonic Wolffian bodies (mesonephros) in relation to nutrition of the breeding hen, has not been previously described, so far as we know. Both types of degeneration observed were generally found in embryos dead at from 17 to 21 days of incubation, when the permanent kidney (metanephros) had become functional. The swollen Wolffian bodies were distended to several times the normal size and were edematous. In cases where the organs were filled with a caseous material, the size was normal but extensive tissue degeneration was apparent.

The type of down termed "clubbed" (figs. 2 and 3 ) results from a failure of the down feather to rupture the surrounding sheath. As a result, the feather is coiled and takes the shape of a French knot. This defect was found in embryos dying at all stages from the first appearance of the 
down feathers to hatching. It was frequently associated with edema, degeneration of the Wolffian bodies, and the dwarf type of embryonic development.

The defect described as "dwarf type" represents stages of development characteristic of the last week of incubation in which the embryo exhibits a marked reduction in size for its comparative physiological development and for the size of the egg. In eggs of normal size, such embryos,

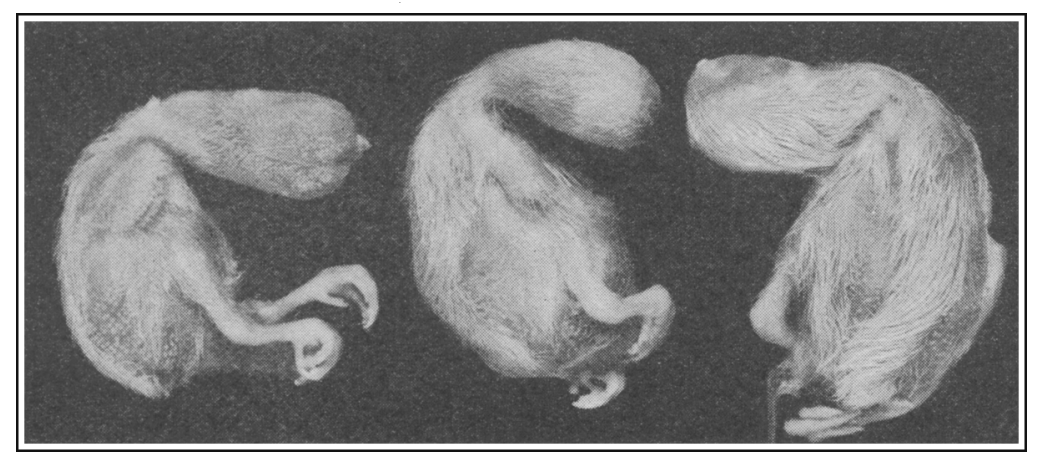

Fig. 3.-Embryos showing varying degrees of expression of clubbed down.

with body size approximating that of a 14- or 15-day normal stage, were found to have the yolk sac enclosed in the abdominal cavity to a degree equivalent to 18- or 19-day normal stages. A retardation in the development of the chick, without a concurrent retardation of the normal physiological sequence of embryonic functions, was apparently responsible for the production of the dwarf-type embryo. Davis, Norris, and Heuser (1938a) also found a retarded development to be a characteristic of riboflavin-deficient embryos.

An apparent anemia in embryos produced by hens fed riboflavin-deficient diets, has been previously described by McFarlane, Fulmer, and Jukes (1930) and by Smith and Branion (1936). Our data likewise (table 7) indicate that riboflavin supplements to rations 1 and 2 were effective in reducing, but not eliminating, the anemic condition. In the case of ration 3, riboflavin supplementation increased the incidence of anemia. These results indicate that more than one factor is probably concerned in the production of anemic embryos. Riboflavin supplementation will apparently reduce the high incidence of embryonic anemia produced by some rations; on others, apparently deficient in some other factor or factors, it proves to be ineffective.

The embryonic mortality curve (fig. 4) obtained in riboflavin deficiency, is characterized by an initial peak at between 1 and 3 days of 
incubation, a pronounced peak at from 10 to 12 days, and a final peak from 19 to 21 days, with approximately equivalent losses in the last two peaks. In all portions of the curve except from 16 to 18 days, and again at 21 days, riboflavin-deficient diets produced markedly more embryonic deaths than the riboflavin-supplemented diets. Our mortality curves differ from those obtained by Davis, Norris, and Heuser (1938a) in that less mortality occurred in the first week of incubation.

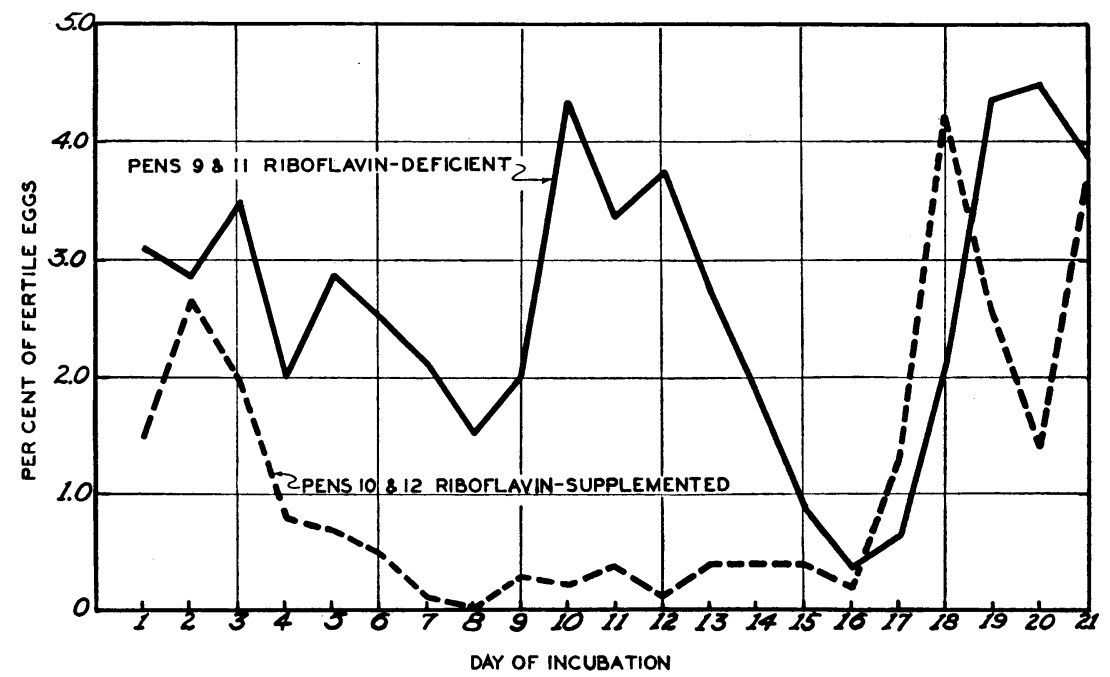

Fig. 4.-Distribution of embryonic mortality on rations with and without riboflavin.

In summarization : riboflavin deficiency in breeding hens' diets produces definite types of defects which seem associated with death of the embryo. Embryos dying in the first week of incubation may be anemic, but not all anemias can be taken as indicative of riboflavin deficiency. In cases of marginal or slight deficiency of the vitamin and early death, only edema and defective down may be produced. In more chronic cases, degeneration of the Wolffian bodies and reduced body size may result. Some disturbance in excretory function may be involved in producing death of the embryos suffering from deficiency of this vitamin.

Ration 3 characteristically produced more chondrodystrophy than either ration 1 or 2 . The average percentages of fertile eggs with chondrodystrophic embryos in case of ration 1 was 0.23 in 1935-36 and 0.52 in 1936-37, of ration 2 was 0.19 , while with ration 3 it was much higher, 3.23. This would indicate (Lyons and Insko, 1937) that ration 3 was probably more deficient in manganese than the other diets. No effect on incidence of chondrodystrophy was produced by supplementing with riboflavin or filtrate factor or both. 


\section{RIBOFLAVIN IN EGGS AS INFLUENCED BY THE RIBOFLAVIN CONTENT OF THE RATION}

The following methods were used to determine the riboflavin content of eggs : (1) chick-growth method, using whole egg as a supplement to a diet deficient in riboflavin; (2) rat-growth method-biological assay of dried whites and dried yolks separately ; (3) colorimetric method, using a photelometer (Sanford, Sheard and Osterberg, 1933), only the whites

TABLE 8

Riboflavin Assay of Eggs Laid May 20-24, 1936, Using the Method of ChICK Grow TH

\begin{tabular}{|c|c|c|c|}
\hline \multirow[b]{2}{*}{ Supplement fed to hens } & \multicolumn{3}{|c|}{ Result of riboflavin assays } \\
\hline & $\begin{array}{c}\text { A verage } \\
\text { gain of chicks, } \\
\text { in grams }\end{array}$ & $\begin{array}{l}\text { Riboflavin } \\
\text { content of } \\
\text { eggs, units } \\
\text { per gram }\end{array}$ & $\begin{array}{c}\text { Micrograms } \\
\text { per gram* }\end{array}$ \\
\hline \multicolumn{4}{|l|}{ Ration 2} \\
\hline 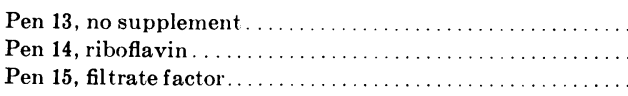 & $\begin{array}{l}24 \\
29 \\
19\end{array}$ & $\begin{array}{l}0.8 \\
1.2 \\
0.5\end{array}$ & $\begin{array}{l}2.2 \\
3.2 \\
1.4\end{array}$ \\
\hline \multicolumn{4}{|l|}{ Ration 1} \\
\hline 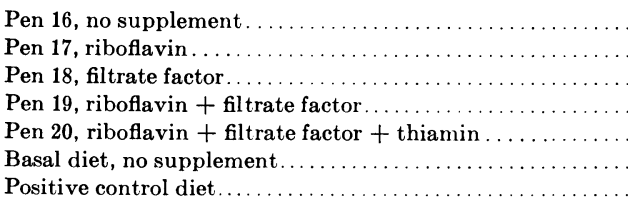 & $\begin{array}{l}23 \\
44 \\
22 \\
47 \\
52 \\
12 \\
60\end{array}$ & $\begin{array}{l}0.8 \\
2.2 \\
0.7 \\
2.4 \\
2.8 \\
\cdots\end{array}$ & $\begin{array}{l}2.2 \\
5.9 \\
1.9 \\
6.5 \\
7.6 \\
\cdots\end{array}$ \\
\hline
\end{tabular}

* Estimated from 1 unit=2.7 micrograms (Jukes, unpublished); calculations based on weight of shellfree, hard-boiled eggs, fed at a level of 30 per cent of the chick diet.

being measured; and (4) indirect method, placing the chicks which hatched from all pens, on a diet low in riboflavin and measuring their growth and viability.

Chick-Growth Method.-Riboflavin assays in 1936 were made by the method of chick growth (Jukes, 1937a). Eggs were boiled for 30 minutes and the shells and membranes were removed. The undried, hard-boiled, shell-free eggs were incorporated with Jukes' diet 96 at a level of 30 per cent. The nutritive ratio of diet 96 was maintained by adjusting the casein content. The mixture was dried at $50^{\circ} \mathrm{C}$. Cod-liver oil and soybean oil were added after drying. Other details of the assay method have been described (Jukes, 1937a). Table 8 summarizes the results. 
Rat-Growth Method.-In testing for riboflavin by the rat-growth method, the eggs were hard-boiled, the whites separated from the yolks and dried under reduced pressure at $100^{\circ} \mathrm{C}$. The dry material was finely ground and given in daily weighed amounts to rats which had already ceased growing on the riboflavin-free diets fed. Crystalline riboflavin was used as the standard of comparison. Groups of 6 rats per lot were fed for 28 days.

Rats receiving whites or yolks from hens on diets containing riboflavin grew about twice as fast as rats receiving the same amount of white or

TABLE 9

Average Growth of Rats When Fed Egg Whites or Yolks* as the ONLy Source of Riboflavin

\begin{tabular}{|c|c|c|}
\hline \multirow{2}{*}{ Supplement fed to hens } & \multicolumn{2}{|c|}{$\begin{array}{l}\text { 28-day gain in weight or } \\
\text { rats fed; in grams }\end{array}$} \\
\hline & Yolks & Whites \\
\hline \multicolumn{3}{|l|}{ Ration $3,1936-37$} \\
\hline 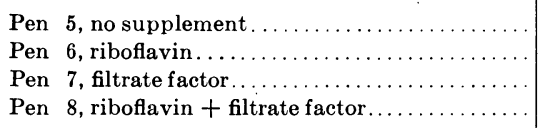 & $\begin{array}{l}30 \\
50 \\
23 \\
48\end{array}$ & $\begin{array}{l}38 \\
83 \\
37 \\
75\end{array}$ \\
\hline \multicolumn{3}{|l|}{ Ration 1, 1936-37 } \\
\hline 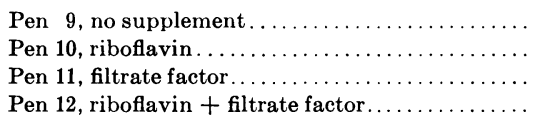 & $\begin{array}{l}28 \\
61 \\
25 \\
57\end{array}$ & $\begin{array}{l}40 \\
80 \\
47 \\
79\end{array}$ \\
\hline $\begin{array}{l}\text { Standard control ( } 5 \text { micrograms riboflavin daily) } \\
\text { Negative controls } \ldots \ldots \ldots \ldots \ldots \ldots \ldots \ldots \ldots \ldots\end{array}$ & \multicolumn{2}{|c|}{$\begin{array}{l}30 \\
\text { Lost weight }\end{array}$} \\
\hline
\end{tabular}

* Rats (except controls) fed 1.0 gram daily of dried yolks or 0.6 gram daily of dried whites.

yolk from eggs laid by hens on diets which were not supplemented with riboflavin (table 9). When the laying hen's diet was not supplemented with riboflavin, 1 gram of dried yolk produced growth approximately equivalent to that of the standard control receiving 5 micrograms of crystalline riboflavin. When the diet of the hen was supplemented with riboflavin, 1 gram of dried yolk apparently contained more than 5 micrograms, although it is impossible to say with certainty how much more, from the data available. Similar comparisons indicate that dried egg white from eggs laid by hens on unsupplemented rations contained about 10 micrograms of riboflavin per gram and considerably more than this 
when the diet of the hen was supplemented with riboflavin. The addition of the filtrate factor seemed to be without influence on the riboflavin content of the egg.

Photelometric Determination of Riboflavin in Egg Whites.-The white of a single egg was coagulated by adding 1 cc of 33 per cent (by volume)

TABLE 10

Photelometric Determination of Riboflavin in Egg Whites of Eggs Laid February 26-May 17, 1937

\begin{tabular}{|c|c|c|c|c|c|c|}
\hline $\begin{array}{l}\text { Ration fed to hens } \\
\text { and pen No. }\end{array}$ & $\begin{array}{l}\text { Egg } \\
\text { No. }\end{array}$ & $\begin{array}{c}\text { Egg weight, } \\
\text { in grams }\end{array}$ & $\begin{array}{l}\text { Volume of } \\
\text { white, in cc }\end{array}$ & $\begin{array}{c}\text { Total } \\
\text { riboflavin } \\
\text { in white, in } \\
\text { micrograms }\end{array}$ & $\begin{array}{c}\text { Riboflavin } \\
\text { per cc of } \\
\text { white, in } \\
\text { micrograms }\end{array}$ & $\begin{array}{l}\text { Appearance of white } \\
\text { before extraction }\end{array}$ \\
\hline
\end{tabular}

Eggs from pens not receiving added riboflavin

\begin{tabular}{|c|c|c|c|c|c|c|}
\hline & 1 & 52.6 & 24.7 & 54 & 2.2 & $\ldots \ldots \ldots \ldots$ \\
\hline \multirow[t]{2}{*}{ Ration 3, pen $5 \ldots}$. & 2 & 48.8 & $17.6^{*}$ & * & 5.6 & Slightly yellow \\
\hline & 3 & 52.8 & 24.8 & 42 & 1.7 & Slightly yellow \\
\hline \multirow{2}{*}{ Ration 3 , pen $7 \ldots$} & 4 & 52.4 & 26.2 & 77 & 2.9 & $\ldots \ldots \ldots \ldots$ \\
\hline & 5 & 46.2 & 21.2 & 81 & 3.8 & Colorless \\
\hline \multirow[t]{2}{*}{ Ration 1, pen $9 \ldots$} & 6 & 50.5 & 24.5 & * 54 & 2.2 & Colorless \\
\hline & 7 & 50.0 & 23.6 & 52 & 2.2 & Slightly yellow, streaky \\
\hline \multirow[t]{2}{*}{ Ration 1 , pen $11 \ldots$} & 8 & 55.0 & 22.2 & 75 & 3.4 & Colorless \\
\hline & 9 & 61.6 & 27.2 & 59 & 2.2 & Colorless \\
\hline Average ........... & . & $\ldots$ & $\ldots$ & 62 & 2.9 & $\ldots \ldots \ldots \ldots$ \\
\hline
\end{tabular}

Eggs from pens receiving added riboflavin

\begin{tabular}{|c|c|c|c|c|c|c|}
\hline Ration 3 , pen $6 \ldots$. & 10 & 49.8 & 19.7 & 92 & 4.7 & Clear, yellowish \\
\hline Ration 3 , pen $8 \ldots$ & $\left\{\begin{array}{l}11 \\
12\end{array}\right.$ & $\begin{array}{l}56.3 \\
54.5\end{array}$ & $\begin{array}{l}25.8 \\
23.0\end{array}$ & $\begin{array}{l}123 \\
125\end{array}$ & $\begin{array}{l}4.8 \\
5.4\end{array}$ & Strongly yellow \\
\hline Ration 1 , pen $10 \ldots$ & $\left\{\begin{array}{l}13 \\
14\end{array}\right.$ & $\begin{array}{l}53.8 \\
60.5\end{array}$ & $\begin{array}{l}25.8 \\
29.5\end{array}$ & $\begin{array}{r}89 \\
170\end{array}$ & $\begin{array}{l}3.4 \\
5.8\end{array}$ & $\begin{array}{l}\text { Strongly yellow } \\
\text { Strongly yellow }\end{array}$ \\
\hline Ration 1 , pen $12 \ldots$ & $\left\{\begin{array}{l}15 \\
16\end{array}\right.$ & $\begin{array}{l}53.7 \\
59.8\end{array}$ & $\begin{array}{l}24.0 \\
27.7\end{array}$ & $\begin{array}{r}86 \\
141\end{array}$ & $\begin{array}{l}3.6 \\
5.1\end{array}$ & Strongly yellow \\
\hline A verage $\ldots . . . \ldots \ldots$ & . & $\ldots$ & $\ldots$ & 118 & 4.7 & $\ldots \ldots \ldots \ldots$ \\
\hline
\end{tabular}

* Some white lost.

sulfuric acid and heating in a boiling-water bath for 5 minutes. The coagulated material was extracted repeatedly with acetone, and the extract was concentrated under reduced pressure to small volume, adjusted to a $\mathrm{pH}$ of between 5 and 6 , and concentrated almost to dryness. The solution was then filtered into a 10-ce volumetric flask and read in the photelometer. A Corning Signal Blue filter was used. 
In the case of whites of eggs from pens receiving added riboflavin, the extracts were much more strongly colored, and a 25 -cc volumetric flask was used instead of a 10-ec flask. This concentration of riboflavin usually gave a reading of between 65 and 80 . The readings were evaluated from a calibration curve constructed empirically from synthetic riboflavin. The results are summarized in table 10.

A riboflavin solution was prepared by the above method from a large batch of egg white. The solution was biologically assayed with chicks in comparison with synthetic riboflavin using the method of Jukes (1937a).

TABLE 11

Effect of Supplement Fed to Breeding Hens on Growth of Baby Chicks Fed a Riboflavin-Deficient DieT

(Chicks from hatch 5 , ration $1,1936-37$ )

\begin{tabular}{|c|c|c|c|c|c|}
\hline Supplement fed to hens & $\begin{array}{c}\text { Number } \\
\text { of } \\
\text { chicks }\end{array}$ & $\begin{array}{l}\text { Weight } \\
\text { at } 3 \text { days, } \\
\text { in grams }\end{array}$ & $\begin{array}{l}\text { Weight } \\
\text { at } 20 \text { days, } \\
\text { in grams }\end{array}$ & $\begin{array}{l}\text { Gain } \\
\text { in } 17 \text { days, } \\
\text { in grams }\end{array}$ & $\begin{array}{c}\text { Mortality, } \\
\text { in } \\
\text { per cent }\end{array}$ \\
\hline Pen 9, no supplement.......... & 25 & 35.2 & 41.7 & 6.5 & 28.0 \\
\hline Pen 10 , riboflavin..... & 25 & 45.4 & 59.3 & 13.9 & 16.0 \\
\hline Pen 11, filtrate factor $\ldots \ldots \ldots \ldots$ & 25 & 42.8 & 45.4 & 2.6 & 8.0 \\
\hline Pen 12 , riboflavin + filtrate factor & 25 & 46.1 & 58.2 & 12.1 & 24.0 \\
\hline
\end{tabular}

The biological value corresponded to only 60 per cent of the photelometric value. If this ratio between photelometric and biological value is consistent for the egg-white extracts, it follows that the whites of eggs from pens not receiving added riboflavin contain an average of 1.7 micrograms per ce of fresh white, or about 15 micrograms per gram of dried white. For pens receiving added riboflavin, the figures are 2.8 micrograms per ce and 23 micrograms per gram. These values may be compared with the values obtained by biological assay with rats (table 9 ).

Riboflavin Content of Eggs as Measured by the Growth and Viability of the Chicks Hatched.-Chicks hatched from eggs laid by hens in pens 9 to 12 inclusive (on ration 1) were placed on diet 96 , low in riboflavin (Jukes, 1937a). Their growth and viability were observed. Altogether, five experiments of this nature were made. Typical data illustrating the results are given in table 11. An insufficient number of chicks was hatched on ration 3 to carry out a similar experiment.

The data indicate that the diet of the laying hen influences the riboflavin content of the egg, which in turn influences the riboflavin stores of the newly hatched chick. Thus the diet of the breeding hen may have a bearing on the vigor of baby chicks as they start life and on their ability to withstand an unfavorable environment.

In the results from the application of all four of the methods used to 
determine the riboflavin stored in the egg, there is substantial agreement. Rations containing supplemental riboflavin uniformly produced eggs having higher concentrations of the vitamin in yolk and white than rations without the supplement.

"Notched Beak"-Is It a Symptom of Riboflavin Deficiency in Chicks? - Chicks hatching from hens on riboflavin-deficient rations had a tendency to develop a lesion on their beaks at the junction of the horny upper beak with the soft tissue (fig. 5). This lesion, which we have termed "notched beak," appeared prominently in chicks from pens 9 and 11 when chicks were put on a riboflavin-deficient ration. The incidence of the "notched beak" lesion in chicks produced in two hatches and fed a ration deficient in riboflavin is given in table 12.

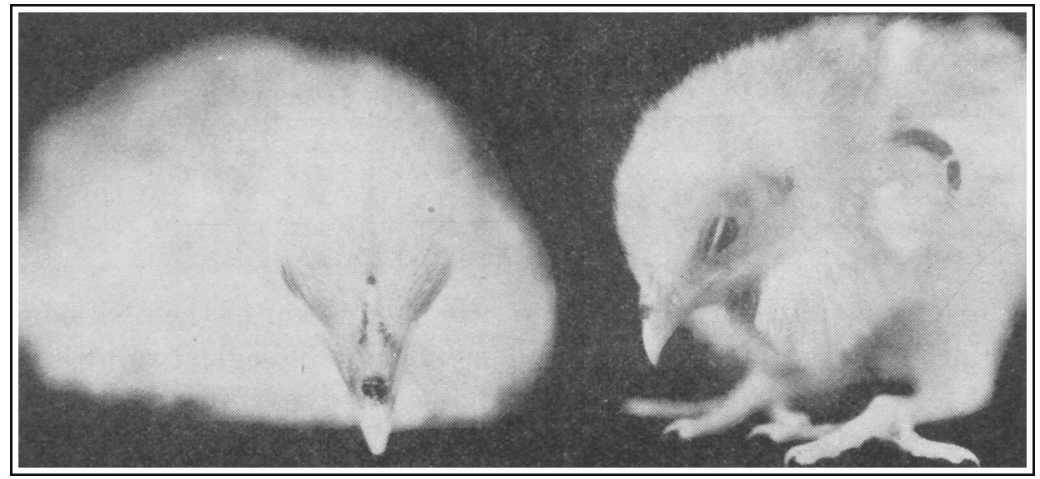

Fig. 5.-Front and side views of the "notched beak" lesion.

In order to make further observations upon the rôle of riboflavin in the incidence of "notched beak" lesions, the chicks from hatch 5 were divided into three groups at the end of the experiment summarized in table 12. In the first group, all the chicks definitely exhibited the "notched beak" lesion. In the second group, the chicks were free from the lesion. The third group consisted of borderline cases. The first and third groups were given supplemental riboflavin, while the second group was continued on the riboflavin-deficient ration. Results are given in table 13.

There seems to be a definite relation between riboflavin and the "notched beak" lesion, since crystalline riboflavin and yeast rich in riboflavin tend to cure the condition. To produce this lesion, the riboflavindeficient diet must be quite free of riboflavin : In a similar test with hatch 4 , in which the casein in the deficient chick ration did not have the riboflavin washed out completely, very few cases of "notched beak" lesions appeared. 
The occurrence of the lesion is evidently sensitive to other factors with which it may be interrelated. Thus, the incidence of "notched beak" was always less when ration 1 was supplemented with riboflavin only (table 12 , pen 10) than when the filtrate factor was added along with the riboflavin (pen 12). The filtrate factor seems to have exerted some inhibiting

TABLE 12

INCIDENCE OF "NotChed BeAK" Lesion, 1936-37

\begin{tabular}{|c|c|c|c|c|c|c|c|c|}
\hline \multirow{3}{*}{$\begin{array}{l}\text { Supplement fed } \\
\text { to hen }\end{array}$} & \multicolumn{4}{|c|}{ Hatch 3} & \multicolumn{4}{|c|}{ Hatch 5} \\
\hline & \multicolumn{2}{|c|}{ Number of chicks } & \multicolumn{2}{|c|}{ "Notched beaks" } & \multicolumn{2}{|c|}{ Number of ehicks } & \multicolumn{2}{|c|}{ "Notched beaks" } \\
\hline & Started & Died & Number & Per cent & Started & Died & Number & Per cent \\
\hline Pen 9, no supplement. & 25 & 7 & 22 & 100 & 25 & 7 & 15 & 84 \\
\hline Pen 10 , riboflavin.... & 25 & 5 & 8 & 40 & 25 & 4 & 4 & 19 \\
\hline $\begin{array}{l}\text { Pen } 11 \text {, filtrate factor. } \\
\text { Pen } 12 \text {, riboflavin }+\end{array}$ & 25 & 6 & 19 & 100 & 25 & 2 & 21 & 91 \\
\hline filtrate factor....... & 25 & 7 & 13 & 70 & 25 & 6 & 14 & 74 \\
\hline
\end{tabular}

TABLE 13

SupPlementary EXPeriment With the "Notched Beak" Lesion (Chicks from hateh $5,1936-37$ )

\begin{tabular}{|c|c|c|c|c|c|c|}
\hline $\begin{array}{l}\text { "Notched } \\
\text { beak" }\end{array}$ & $\begin{array}{l}\text { Number } \\
\text { of chicks }\end{array}$ & $\begin{array}{l}\text { Supplement to low } \\
\text { riboflavin ration }\end{array}$ & $\begin{array}{l}\text { Average } \\
\text { weight } \\
\text { at start, } \\
\text { in grams }\end{array}$ & $\begin{array}{c}\text { Average } \\
\text { weight } 2 \\
\text { weeks later, } \\
\text { in grams }\end{array}$ & $\begin{array}{l}\text { Gain, } \\
\text { in grams }\end{array}$ & $\begin{array}{c}\text { Per cent } \\
\text { of } \\
\text { "notched } \\
\text { beak" }\end{array}$ \\
\hline Definite & 27 & $\begin{array}{l}25 \mathrm{mg} \text { crystalline riboflavin } \\
\text { per kilo of ration.......... }\end{array}$ & 54.3 & 100.0 & 43.7 & 8.7 \\
\hline None & 27 & None.................... & 53.8 & 71.6 & 17.8 & 42.2 \\
\hline Borderline & 19 & 5 per cent brewers' yeast.... & 50.3 & 106.2 & 55.9 & 26.3 \\
\hline
\end{tabular}

effect on the ability of riboflavin to prevent the "notched beak" lesion. Moreover, although yeast promoted greater growth in the chick (table $13)$, it was less effective than riboflavin in preventing and curing the "notched beak" lesion. This observation is difficult to interpret, since the yeast adds other factors than riboflavin. There is possibly an interrelation between riboflavin and some other factor. 


\section{STORAGE OF RIBOFLAVIN IN THE MUSCLES AND LIVER TISSUES OF LAYING HENS AS INFLUENCED BY THE RIBOFLAVIN CONTENT OF THE RATION}

At the termination of the investigations of 1936-37, the livers and breast muscles of the laying hens were removed and dried, and their riboflavin content estimated by the rat-growth method. The dry muscles were fed without further treatment, but the livers were treated with a hydrocarbon solvent (boiling point $60^{\circ}-72^{\circ} \mathrm{C}$ ) to extract the fat and were then

\section{TABLE 14}

Riboflavin Content of Muscles and Livers of Laying Hens AS Determined by Rat Growth, 1936-37

(1.5 gram muscle and 0.05 gram liver fed daily)

\begin{tabular}{|c|c|c|}
\hline \multirow{2}{*}{ Ration and supplement fed to hens } & \multicolumn{2}{|c|}{$\begin{array}{l}\text { 28-day gains in weight, } \\
\text { in grams }\end{array}$} \\
\hline & On muscle & On liver \\
\hline \multicolumn{3}{|l|}{ Ration 3} \\
\hline 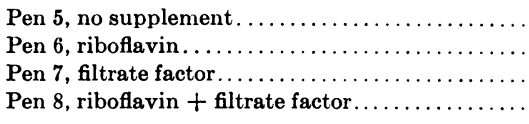 & $\begin{array}{l}35 \\
37 \\
27 \\
35\end{array}$ & $\begin{array}{l}16 \\
19 \\
20 \\
31\end{array}$ \\
\hline \multicolumn{3}{|l|}{ Ration 1} \\
\hline 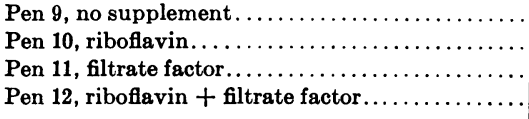 & $\begin{array}{l}18 \\
27 \\
26 \\
48\end{array}$ & $\begin{array}{l}31 \\
25 \\
21 \\
27\end{array}$ \\
\hline
\end{tabular}

fed to rats which had ceased to gain on riboflavin-free rations. Six rats were used in each group and were fed muscle and liver supplements for 28 days. The results are shown in table 14 .

The results vary irregularly and have no correlation with the riboflavin content of the ration of the laying hen. There is no clear evidence that the character of the ration affected the storage of riboflavin in the muscles or the liver.

\section{THE EFFECT OF RIBOFLAVIN ON THE FAT AND PROTEIN CONTENT OF LIVERS OF THE HENS}

On grinding, the dry livers were found to vary markedly in their physical properties, that is, from a granular to an oily consistency. They were accordingly analyzed for fat, protein, and moisture. The results are detailed in table 15. They are based on the dry weight of the liver. 
In every case, livers from hens fed a low-riboflavin diet were heavier and contained considerably more fat than those from hens on high-riboflavin diets. Sebrell, Onstott, and Hunt (1937) have found that riboflavindeficient dogs develop yellow livers, which, presumably, results from an excessive deposition of fat. As is to be expected, the protein content of the liver varies inversely with the fat content.

TABLE 15

Fat and Protein Content of Livers of Hens, 1936-37

\begin{tabular}{|c|c|c|c|}
\hline Ration and supplement fed to hens & $\begin{array}{c}\text { Average } \\
\text { fresh weight } \\
\text { of liver } \\
\text { per hen, } \\
\text { in grams }\end{array}$ & $\begin{array}{l}\text { Per cent } \\
\text { protein, } \\
\text { dry basis }\end{array}$ & $\begin{array}{l}\text { Per cent } \\
\text { fat, } \\
\text { dry basis }\end{array}$ \\
\hline \multicolumn{4}{|c|}{ Ration 3} \\
\hline Pen 5, no supplement... & 200 & 45.27 & 39.63 \\
\hline Pen 6 , riboflavin....... & 142 & 52.06 & 30.33 \\
\hline Pen 7 , filtrate factor............... & 229 & 43.02 & 44.01 \\
\hline Pen 8 , riboflavin + filtrate factor.... & 169 & 52.10 & 32.76 \\
\hline \multicolumn{4}{|c|}{ Ration 1} \\
\hline Pen 9 , no supplement.............. & 282 & 50.14 & 37.54 \\
\hline Pen 10 , riboflavin..$\ldots \ldots \ldots \ldots \ldots$ & 256 & 55.91 & 31.84 \\
\hline Pen 11 , filtrate factor.............. & 301 & 46.06 & 37.68 \\
\hline Pen 12 , riboflavin + filtrate factor.... & 208 & 61.03 & 27.66 \\
\hline
\end{tabular}

\section{STORAGE OF THE FILTRATE FACTOR IN EGGS}

Two methods were used to study the influence of the feed on the filtratefactor content of the eggs : (1) the direct method of measurement of the filtrate factor values of the eggs by feeding tests using the method of Jukes (1937b), and (2) the indirect method, by hatching the eggs and putting the chicks on the low filtrate factor diet $80 \mathrm{G}$ (Jukes, 1937b), and observing growth and the development of dermatitis.

Biological Assay of Eggs for Filtrate Factor.-The biological assay is based upon growth of chicks (Lepkovsky and Jukes, 1935, Jukes, 1937b) fed eggs from the various pens. The eggs were boiled for 20 minutes, and the shells and membranes were removed. The undried, shell-free, hardboiled eggs were incorporated with the heated diet $80 \mathrm{G}$ at a definite level, usually between 21 and 25 per cent, by weight. The composition of the heated diet $80 \mathrm{G}$ was modified by adjusting the casein and cornmeal content to preserve its original nutritive ratio. The mixture of eggs and diet was allowed to dry at room temperature (usually about $35^{\circ} \mathrm{C}$ ). The 
TABLE 16

Assay of Eggs for Filtrate Factor, Using the Method of Chick Growth

\begin{tabular}{l|c|c|}
\hline \hline Supplement fed to hens & Date eggs were laid & $\begin{array}{c}\text { Filtrate factor, } \\
\text { units per gram } \\
\text { of shell-free } \\
\text { hard-boiled } \\
\text { eggs* }\end{array}$ \\
\hline
\end{tabular}

Ration 2, 1935-36

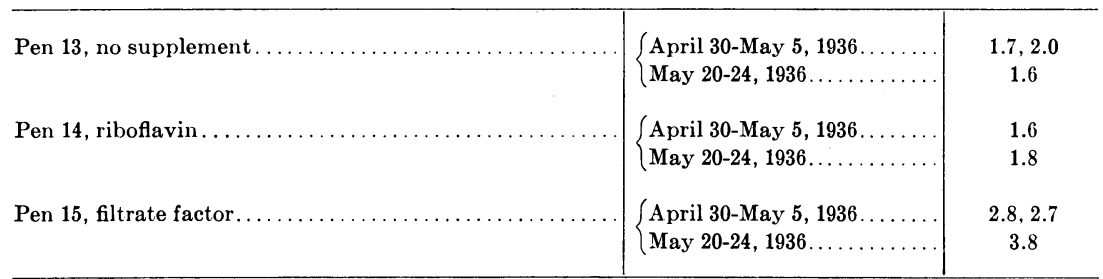

Ration 1, 1935-36

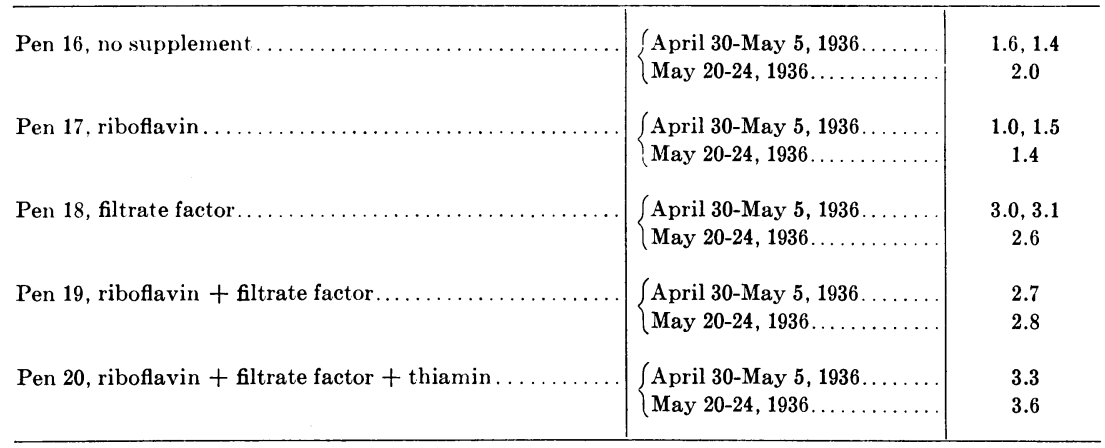

Ration 3, 1936-37

Pen 5, no supplement.

Pen 6, riboflavin.

Pen 7, filtrate factor.

Pen 8 , riboflavin + filtrate factor
March 12-14, 1937.

March 12-14, 1937

March 12-14, 1937

March 12-14, 1937
$0.6,0.7$

$0.8,0.5$

$1.5,2.7$

$1.5,1.0$

\section{Ration 1, 1936-37}

\begin{tabular}{|c|c|c|}
\hline Pen 9 , no supplement.... & March $12-14,1937 \ldots \ldots$ & $0.8,1.2$ \\
\hline Pen 10 , riboflavin $\ldots . . \ldots$ & March $12-14,1937$. & $1.2,1.4$ \\
\hline Pen 11 , filtrate factor . . . . . . . . . . & March $12-14,1937 \ldots$ & $1.6,2.7$ \\
\hline Pen 12 , riboflavin + filtrate factor $\ldots \ldots \ldots \ldots \ldots \ldots$ & March $12-14,1937 \ldots \ldots \ldots \ldots$ & $2.2,2.8$ \\
\hline
\end{tabular}

* Each value represents the result of an assay. 
diet was then fed to chicks in the manner described by Jukes (1937b). Table 16 summarizes the results. Each value in column 3 represents a biological assay with a group of 9 or 10 chicks.

The results indicate that the filtrate-factor content of the egg is influenced to a marked degree by the diet of the hen. Of interest is the low filtrate-factor content of eggs from pens 5 and 6, laid by hens which

\section{TABLE 17}

Growth and Symptomatology of Baby Chicks Fed Diet $80 \mathrm{G}$, Deficient IN THE Filtrate Factor

\begin{tabular}{c|c|c|c|c}
\hline Supplement fed to hen & $\begin{array}{c}\text { Number of } \\
\text { chicks }\end{array}$ & $\begin{array}{c}\text { Gain* } \\
\text { in grams, }\end{array}$ & $\begin{array}{c}\text { Dermatitist } \\
\text { syndrome } \\
\text { score }\end{array}$ & $\begin{array}{c}\text { Filtrate factor } \\
\text { unit per gram } \\
\text { of egg } \\
\text { (from table 16) }\end{array}$ \\
\hline
\end{tabular}

Chicks from hatch 5 , ration 2, 1935-36

\begin{tabular}{|c|c|c|c|c|}
\hline Pen 13 , no supplement $\ldots \ldots \ldots \ldots \ldots \ldots \ldots$ & 24 & 4 & 1.5 & 1.8 \\
\hline Pen 14 , riboflavin..$\ldots \ldots \ldots \ldots \ldots \ldots$ & 25 & 5 & 1.5 & 1.7 \\
\hline Pen 15 , filtrate factor $\ldots \ldots \ldots \ldots \ldots \ldots$ & 27 & 9 & 1.1 & 3.1 \\
\hline
\end{tabular}

Chicks from hatch 2 , ration $1,1935-36$

\begin{tabular}{|c|c|c|c|c|}
\hline Pen 16 , no supplement..... & 11 & 2 & 1.6 & 1.7 \\
\hline Pen 17 , riboflavin $\ldots \ldots \ldots \ldots \ldots$ & 24 & 4 & 2.1 & 1.3 \\
\hline Pen 18, filtrate factor $\ldots \ldots \ldots \ldots \ldots$ & 24 & 9 & 0.5 & 2.9 \\
\hline Pen 19, riboflavin + filtrate factor . . . . . . & 25 & 5 & 2.1 & 2.8 \\
\hline Pen 20 , riboflavin + filtrate factor + thiamin. & 24 & 3 & 1.5 & 3.5 \\
\hline
\end{tabular}

Chicks from hatch 2 , ration $1,1936-37$

\begin{tabular}{|c|c|c|c|c|}
\hline Pen 9, no supplement... & 25 & 12 & 0.9 & 1.0 \\
\hline Pen 10 , riboflavin $\ldots . .$. & 25 & 8 & 2.3 & 1.3 \\
\hline Pen 11, filtrate factor $\ldots \ldots \ldots \ldots$ & 22 & 16 & 0.1 & 2.2 \\
\hline Pen 12 , riboflavin + filtrate factor . . . . . . & 25 & 14 & 0.6 & 2.5 \\
\hline
\end{tabular}

* The gain in weight for pens 13-20 represents the increase in weight between 7 and 16 days of age; for pens $9-12$, between 4 and 18 days of age.

$\dagger$ The syndrome score in pens 13-20 was taken at 16 days of age; in pens 9-12 at 18 days of age. Syndrome score as here used was as determined by Lepkovsky and Jukes (1935) except that grades of 1 to 4 were assigned instead of 10 to 40 .

received ration 3 without a filtrate-factor supplement. These data indicate that ration 3 contained less filtrate factor than either rations 1 or 2 .

Growth and Symptomatology of Chicks Hatched.-The second method of measuring the filtrate-factor content of eggs involved an attempt to measure the storage of the factor in chicks hatched from eggs laid by hens on the different rations. These chicks were fed a ration deficient in the filtrate factor. Increases in weight and the severity of dermatitis, measured by the syndrome score, were recorded to an age of from 16 to 18 days. Data are given in table 17. The approximate filtrate factor units per gram of egg in this table are averages derived from table 16. 
Chicks hatched from eggs laid by hens receiving rations supplemented with the filtrate factor grew somewhat more rapidly and developed dermatitis more slowly when placed on a deficient diet than did the chicks hatched from eggs laid by hens receiving a filtrate-factor supplement. However, the correlation between these measures of storage in the chick and the filtrate-factor content of the egg as measured by biological assay was not consistent. In several instances, the addition of riboflavin to the diet of the hen appeared to have some effect in provoking the symptoms of filtrate-factor deficiency in chicks. This may have been partly due to an interaction of an unknown nature between riboflavin and the filtrate factor.

From the above tests, it is evident that the filtrate-factor content of the egg is correlated with that of the ration fed the laying hen. There is also evidence that the higher filtrate-factor content of the egg is related to a better quality of the chick hatched with respect to resistance against filtrate-factor deficiency.

\section{GENERAL DISCUSSION}

Two water-soluble vitamins of the vitamin-G complex have been demonstrated to be inadequately supplied in certain practical as well as experimental rations. These are riboflavin and the filtrate factor.

The addition of filtrate-factor supplements to rations of the types studied in this investigation apparently exerts no influence on egg production, hatchability, or the character of the embryonic mortality. The filtrate factor, however, cannot be ignored because the amount of this vitamin in the egg from which the baby chick must derive its initial supply to start life is dependent on the filtrate-factor content of the laying hen's ration. Practically, this may be important only when the chick ration is marginally deficient in the filtrate factor, which plays an important rôle in the prevention of dermatitis and promotion of growth.

The riboflavin content of the laying hen's ration is important in determining the number of eggs laid, and, in even greater degree, the ability of eggs laid to hatch into vigorous chicks. In the absence of a sufficient amount of riboflavin in the laying hen's diet, eggs will be laid containing little riboflavin. This can be seen directly by breaking the egg and examining the egg white, which will be practically colorless from hens on low riboflavin diets or a greenish yellow from hens fed adequate rations. That the color of the egg white is a fairly good index of its riboflavin content has been confirmed by assays using the rat-growth method for measuring riboflavin.

Eggs failing to hatch for lack of sufficient riboflavin show character- 
istic embryonic abnormalities. Prominent among these are : degeneration of the Wolffian bodies, deformed down, edema, reduced size, and anemia. Of interest is the defect in down formation, indicating a disturbance in the skin, since riboflavin deficiency in the rat is also associated with generalized skin defects. In the growing chick, however, no such disturbance has previously been reported. The reduced size of the embryo (dwarf type) is probably a consequence of the essential nature of riboflavin for growth. The appearance of anemia is interesting. Blood studies on deficiencies of the vitamin-G complex have indicated that anemia may be associated with deficiency of members of this group (Kohls, 1932). Riboflavin may be one of the factors concerned in the maintenance of a normal blood stream. Only edema and kidney degeneration in the dead embryos have no counterpart in reported disturbances of growing experimental animals on riboflavin-deficient diets. This information should stimulate search for similar physiological disturbances in other young riboflavindeficient animals.

A matter of special significance brought to light by these investigations is the interrelation of riboflavin and other factors, as yet of an unknown nature. While with rations composed primarily of cereals, cereal by-products, and fish meal, riboflavin will promote egg production and hatchability, yet on a ration composed primarily of polished rice and fish meal, it not only does not improve egg production and hatchability but actually decreases them. Evidently, the polished rice lacks a factor which has so far escaped detection and which, like riboflavin, is apparently essential for egg production and hatchability. Moreover, this factor apparently has a physiological function so related to that of riboflavin that a balance of some kind may be assumed. When this unknown factor is inadequately supplied, the balance between it and riboflavin is destroyed, so that the presence of riboflavin may indeed be harmful. This seems a logical explanation for the detrimental effect of riboflavin when added to ration 3. It calls attention to the probability that the balance of the constituent parts of the ration must receive an increased amount of attention.

Further evidence of the interaction of vitamins is that found between riboflavin and some component of the filtrate-factor concentrates. Riboflavin in the laying ration was more effective in preventing the development of the "notched beak" lesion of the baby chicks when no filtratefactor concentrate was added to the hen's ration. Moreover, adequate riboflavin in the hen's diet led to greater storage of riboflavin in the baby chick. This apparently increased the severity of the dermatitis of growing chicks on the low-filtrate-factor ration, especially when no filtrate- 
factor concentrate was added to the hen's ration. These results suggest the advisability of considering the balance of the vitamins supplied in practical poultry rations.

On low-riboflavin rations, the livers of laying hens were higher in fat than were the livers of hens receiving an adequate amount of riboflavin. This observation draws attention to the lack of information on the rôle of the liver in the fat metabolism of the laying hen. Apparently a fatty liver is normal for an actively laying hen, but how high the percentage of fat in the liver can go and the bird still remain normal, is not known. It is, therefore, difficult to interpret the increased fat content of the livers of laying hens on low riboflavin feeds, but the regularity with which the low-riboflavin rations studied here gave increased liver fats probably is not without significance. Cases of fatty degeneration of the liver are not uncommonly found in routine autopsy work on fowls raised under practical conditions.

While certain important conditions involved in egg production and hatchability may now be definitely related to specific known vitamins, the evidence suggesting interactions between these vitamins and the evidence for factors as yet unidentified may also be important results obtained in this work.

\section{CONCLUSIONS}

Of the water-soluble vitamins, riboflavin is of primary importance in sustaining good hatchability. It is also important for high winter egg production of hens. There is evidence that some practical poultry rations may not contain enough of this vitamin for maximum egg production and hatchability.

Riboflavin deficiency in hens is associated with an increased fat content of the liver.

Riboflavin deficiency in eggs can be detected by the lack of a pronounced greenish-yellow color of the albumen and by characteristic defects in the embryos developed in the eggs after a period of incubation.

The filtrate factor, under the conditions studied, seems to have no function in maintaining normal egg production or hatchability. It is, however, important in producing a chick resistant to a dermatitis caused by a deficiency of this vitamin.

The riboflavin and the filtrate-factor content of eggs is directly influenced by the diet of the hen.

Evidence is presented concerning the essential nature of an unidentified factor influencing the health and reproduction of hens fed a ration consisting largely of polished rice and fish meal.

The importance of vitamin interactions in the proper balancing of rations is indicated by results obtained in this investigation, 


\section{ACKNOWLEDGMENTS}

We wish to acknowledge with thanks the help received in carrying out this work. Dr. I. Michael Lerner assisted in the calculation of statistical data. The riboflavin fuller's-earth adsorbates and filtrate-factor concentrates were obtained through the courtesy of Mr A. K. Humphries of the Vitab Products, Inc., Emeryville, California. The refined soybean oil was obtained from the Durkee Famous Foods, Berkeley, California, through the courtesy of Mr. Dean C. Ingraham. The extracted fish meal was obtained from the F. E. Booth Co., San Francisco, through Mr. T. D. Sanford. The cod-liver oil was obtained from Mead Johnson and Co., Evansville, Indiana, through the courtesy of Mr. Masterman. The washliquor residue from milk sugar was obtained from the California Milk Products Co., Gustine, California, through Mr. Joseph Chrisman. The photelometer used in the photelometric determinations of riboflavin in egg whites was donated by the Fernando Valley Milling and Supply Co., Los Angeles; Mr. Charles L. Welch aided in this part of the experiment; and Dr Paul György, of the University Hospital, Cleveland, Ohio, supplied the synthetic riboflavin used in constructing the calibration curve for these determinations. The work was aided by a financial grant from Eli Lilly and Co, Indianapolis, through the courtesy of Mr. H. W. Rhodehamel. We are also indebted to the W.P.A. for their support with materials and personnel under Project A. P. No. 465-03-3-209. 


\section{LITERATURE CITED}

Almquist, H. J., and E. L. R. Stokstad.

1935. Hemorrhagic chick disease of dietary origin. Jour. Biol. Chem. 111:105-13.

Bender, R. C., and G. C. Supplee.

1937. Significance of quantitative relationships in vitamin B complex studies. Jour. Amer. Chem. Soc. 59:1178-82.

BethKe, R. M., and D. C. KENNARD.

1928. Producing hatchable eggs. Ohio Agr. Exp. Sta. Bimonthly Bul. 13:210-16.

BETHKe, R. M., P. R. ReCORD, and D. C. KenNaRD.

1933. Relation of the vitamin $\mathrm{G}$ complex to hatchability and the nutritive value of eggs. Poultry Sci. 12:332-33.

1936. The relation of vitamin $G$ to the hatchability of hens' eggs. Jour. Nutrition 12:297-307.

BIRCH, T. W., P. GyörgY, and L. J. HARRIS.

1935. The vitamin $B_{2}$ complex. Differentiation of the antiblack tongue and the "P-P" factors from lactoflavin and vitamin $\mathrm{B}_{\mathrm{b}}$ (so-called "rat pellagra" factor). Biochem. Jour. 19:2830-50.

Bourquin, A., and H. C. Sherman.

1931. Quantitative determination of vitamin $G\left(B_{2}\right)$. Jour. Amer. Chem. Soc. 53: 3501-5.

Davis, H. J., L. C. Norris, and G. F. Heuser.

1938a. The rôle of vitamin G in reproduction in poultry. Poultry Sci. 17:81-86.

$1938 \mathrm{~b}$. Further evidence on the amount of vitamin G required for reproduction in poultry. Poultry Sci. 17:87-93.

ElvenJem, C. A., and C. J. Koghn, JR.

1935. Studies on vitamin $B_{2}(G)$. The non-identity of vitamin $B_{2}$ and the flavins. Jour. Biol. Chem. 108:709-28.

Euler, H. V., P. Karrer, M. Malmberg, K. Schöpp, F. Benz, B. Becker, and P. Frei.

1935. Synthese des Lactoflavins (vitamin $B_{2}$ ) und anderer Flavine. Helvetica Chim. Acta 18:522-35.

Halpin, J. G., C. E. Holmes, and E. B. HaRT.

1933. Vitamin $\mathrm{G}$ inadequate in many rations for laying hens. In: Christensen, $\mathrm{C}$. L., and Noble Clark. Facts for farmers. Wisconsin Agr. Exp. Sta. Bul. 425:18-19.

Heiman, V.

1935. The relative vitamin G content of dried whey and dried skim milk. Poultry Sci. 14:137-46.

JukEs, T. H.

1937a. Biological assay of lactoflavin with chicks. Jour. Nutrition 14:223-33.

$1937 b$. Further observations on the assay, distribution, and properties of the filtrate factor. Jour. Biol. Chem. 117:11-20.

KoHls, Clara L.

1932. Blood picture in vitamin-G deficiency. [Abstract.] Anat. Rec. 52:62.

KuHN, R., P. GYöRGY, and T. WAGNER-JAUREGG.

1933. Ưber Lactoflavin, den Farbstoff der Molke. Ber. Deut. Chem. Gesell. 66: $1934-38$.

KuHN, R., H. RUDY, and T. WAGNER-JAUREGG.

1933. Über Lactoflavin (vitamin $B_{2}$ ). Ber. Deut. Chem. Gesell. 66:1950-56. 
LEPKovsky, S., and T. H. JUKE.S.

1935. The vitamin G requirements of the chick. Jour. Biol. Chem. 111:119-31.

Lepkovsky, S., T. H. Jukes, and M. E. Krause.

1936. The multiple nature of the third factor of the vitamin B complex. Jour. Biol. Chem. 115:557-66.

Lyons, M., and W. M. Insko, JR.

1937. Chondrodystrophy in the chick embryo produced by manganese deficiency in the diet of the hen. Kentucky Agr. Exp. Sta. Bul. 371:63-75.

McCollum, E. V., and N. STMmonds.

1918. A study of the dietary essential water-soluble $B$ in relation to the solubility and stability towards reagents. Jour. Biol. Chem. 33:55-89.

McFarlane, W. D., H. L. Fulmer, and T. H. Jukes.

1930. Studies in embryonic mortality in chicks. I. The effect of diet upon the nitrogen, tyrosine, tryptophane, cystine, and iron content of the proteins and on the total copper of the hen's eggs. Biochem. Jour. 24:1611-30.

Poley, W. E., A. L. Moxon, and K. W. Franke.

1937. Further studies of the effects of selenium poisoning on hatchability. Poultry Sci. 16:219-25.

Ringrose, A. T., L. C. Norris, and G. F. Heuser.

1931. The occurrence of a pellagra-like syndrome in chicks. Poultry Sci. 10:166-77.

SANFORD, A. H., C. SHEARD, and A. E. Osterberg.

1933. The photelometer and its use in the clinical laboratory. Amer. Jour. Clin. Path. 3-405-20.

Sebrell, W. H., R. H. ONstotT, and D. J. Hunt.

1937. The treatment of black tongue with a preparation containing the "filtrate factor" and evidence of riboflavin deficiency in dogs. Pub. Health Repts. [U. S.] 52:427-33.

Sherman, H. C., and S. L. SMITH.

1931. The vitamins. 2nd ed. The Chem. Catalog. Co. Inc., New York, N. Y.

Smith, J. B., and H. D. Branion.

1936. Hatchability studies with certain feeds. Wiss. Ber. des VI. Weltgeflügel Kong. 2:77-83. Uschmann in Weimar, Germany.

Titus, H. W., T. C. ByerLy, and N. R. Ellis.

1933. Effect of diet on egg composition. I. Partial chemical analysis of eggs produced by pullets on different diets. Jour. Nutrition 6:127-38. 
